\title{
How human T-cell leukemia virus type 1 induces diseases
}

\author{
Masao Matsuoka \\ From Frontiers of Retrovirology: Complex retroviruses, retroelements and their hosts \\ Cambridge, UK. 16-18 September 2013
}

Human T-cell leukemia virus type1 (HTLV-1) is the causal agent of adult T-cell leukemia (ATL), and inflammatory diseases, such as HTLV-1 associated myelopathy (HAM), uveitis, alveolitis and infective dermatitis. Approximately, 5\% of carrier will develop ATL after a long latent period. A characteristic of this virus is that HTLV-1 can transmit only by cell-to-cell contact. Therefore, HTLV-1 increases infected cells in vivo to facilitate its transmission.

Previous studies suggest that Tax plays central roles in leukemogenesis by HTLV-1. However, Tax expression is frequently impaired in ATL cells. The HTLV-1 bZIP factor $(H B Z)$ gene is transcribed from minus strand of provirus using 3' long terminal repeat (LTR) as the promoter/ enhancer. Among ATL cases, only the $H B Z$ gene is expressed in all ATL cases, suggesting an importance of the $H B Z$ gene in ATL cells. Indeed, transgenic expression of the $H B Z$ gene induced T-cell lymphoma and inflammatory diseases. Furthermore, regulatory $\mathrm{T}$ (Treg) cells increased in HBZ-transgenic (HBZ-Tg) mice. As a mechanism, HBZ induces transcription of the Foxp3 gene through enhanced Smad/ TGF- $\beta$ pathway and converts infected cells to Treg cells. Concurrently, HBZ impairs function of Treg via interaction of HBZ with Foxp3 and associated factors. Thus, HBZ increases functionally impaired Treg cells in vivo, which resembles to phenotype of HTLV-1 infected cells and ATL cells. It is speculated that HTLV-1 infected Treg cells escape the host immune surveillance by acquired phenotype of Treg cells. Treg cells derived from HBZTg mice progressively lost Foxp3 expression in vitro and produced IFN- $\gamma$, indicating that HBZ induces inflammation through unstable Foxp3 expression. Thus, HBZ is responsible for both $\mathrm{T}$-cell lymphoma and inflammatory diseases.

Institute for Virus Research, Kyoto University, Japan
HBZ has pleiotropic functions as well as Tax. HBZ enhances TGF- $\beta$ /Smad pathway while Tax inhibits it. Likewise, HBZ suppresses canonical NF- $\kappa \mathrm{B}$ whereas Tax activates canonical and noncanonical NF- $\kappa \mathrm{B}$ pathways. Thus, HBZ has opposite effects to Tax in many pathways. Interplay between HBZ and Tax likely coordinates to promote viral replication and proliferation of infected cells, leading to important roles in the pathogenesis.

Published: 19 September 2013

doi:10.1186/1742-4690-10-S1-015

Cite this article as: Matsuoka: How human T-cell leukemia virus type 1 induces diseases. Retrovirology 2013 10(Suppl 1):015.

Submit your next manuscript to BioMed Central and take full advantage of:

- Convenient online submission

- Thorough peer review

- No space constraints or color figure charges

- Immediate publication on acceptance

- Inclusion in PubMed, CAS, Scopus and Google Scholar

- Research which is freely available for redistribution (c) 2013 Matsuoka; licensee BioMed Central Ltd. This is an Open Access article distributed under the terms of the Creative Commons Attribution License (http://creativecommons.org/licenses/by/2.0), which permits unrestricted use, distribution, and reproduction in any medium, provided the original work is properly cited. 